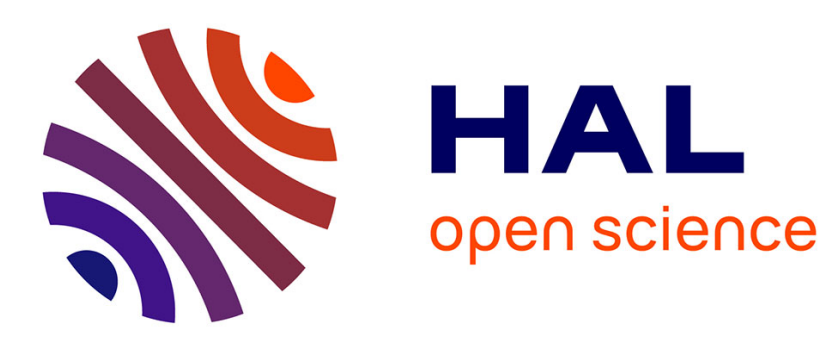

\title{
DNA adduct formation by ochratoxin A?: A review of the available evidence
}

\author{
Wolfgang Dekant
}

\section{To cite this version:}

Wolfgang Dekant. DNA adduct formation by ochratoxin A?: A review of the available evidence. Food Additives and Contaminants, 2005, 22 (S1), pp.65. 10.1080/02652030500317544 . hal-00578284

\section{HAL Id: hal-00578284 \\ https://hal.science/hal-00578284}

Submitted on 19 Mar 2011

HAL is a multi-disciplinary open access archive for the deposit and dissemination of scientific research documents, whether they are published or not. The documents may come from teaching and research institutions in France or abroad, or from public or private research centers.
L'archive ouverte pluridisciplinaire HAL, est destinée au dépôt et à la diffusion de documents scientifiques de niveau recherche, publiés ou non, émanant des établissements d'enseignement et de recherche français ou étrangers, des laboratoires publics ou privés. 


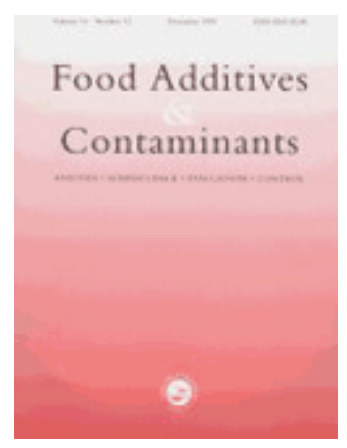

\section{DNA adduct formation by ochratoxin A?: A review of the available evidence}

\begin{tabular}{|r|l|}
\hline Journal: & Food Additives and Contaminants \\
\hline Manuscript ID: & TFAC-2005-224 \\
\hline Manuscript Type: & Review \\
\hline $\begin{array}{r}\text { Date Submitted by the } \\
\text { Author: }\end{array}$ & 04-Aug-2005 \\
\hline Complete List of Authors: & $\begin{array}{l}\text { Dekant, Wolfgang; University of Würzburg, Department of } \\
\text { Toxicology }\end{array}$ \\
\hline Methods/Techniques: & Toxicology \\
\hline Additives/Contaminants: & Mycotoxins - ochratoxin A \\
\hline Food Types: & \\
\hline
\end{tabular}




\title{
DNA adduct formation by ochratoxin A?: A review of the
}

\section{available evidence}

\author{
Angela Mally and Wolfgang Dekant ${ }^{*}$ \\ Department of Toxicology, University of Würzburg, Versbacher Str. 9, 97078 Würzburg, \\ Germany
}

\begin{abstract}
The mycotoxin ochratoxin A (OTA) is a potent nephrotoxin and renal carcinogen in rodents. However, the mechanism of OTA-induced tumour formation is unknown and conflicting results regarding the potential of OTA to react with DNA have been obtained. While experiments using radiolabelled $\left({ }^{3} \mathrm{H}\right.$ or $\left.{ }^{14} \mathrm{C}\right)$ OTA and liquid scintillation counting or accelerator mass spectrometry indicate lack of formation of covalent DNA-adducts, spots detected by ${ }^{32} \mathrm{P}$-postlabelling have been attributed to treatment with OTA. However, these putative DNA-adducts have not been shown to contain OTA or part of the OTA molecule and so far no structural information has been provided. Consistent with the absence of DNAbinding of radiolabelled OTA, studies on biotransformation in vivo and in vitro indicate that OTA is poorly metabolized and does not form reactive intermediates capable of interacting with DNA. Recently however, the structures of a carbon- and an oxygen-bonded OTAdeoxyguanosine adduct which is formed by photoirradiation of OTA in the presence of deoxyguanosine have been reported and suggested to be involved in OTA carcinogenicity. The aim of this manuscript is to provide an overview of the available literature regarding DNA adduct formation by OTA.
\end{abstract}

Keywords: Ochratoxin A, carcinogenicity, DNA-adducts 


\section{Introduction}

Ochratoxin A (OTA) (N-\{[(3R)-5-chloro-8-hydroxy-3-methyl-1-oxo-7-isochromanyl]carbonyl \}-3-phenyl-L-alanine) is a mycotoxin produced by Aspergillus and Penicillium species. OTA may contaminate a variety of food items such as cereals, coffee, wine etc., resulting in chronic human exposure. OTA is nephrotoxic and induces renal tumours in rodents, whereby it exhibits significant sex- and species differences (NTP, 1989). Male rats are most susceptible to OTA carcinogenicity and repeated administration of low doses of OTA (up to $210 \mu \mathrm{g} / \mathrm{kg}$ b.w.) for two years results in high incidences of renal adenomas and carcinomas arising from the straight segment (S3) of the proximal tubule epithelium (NTP, 1989; Boorman et al., 1992). Interestingly, no increase in tumour incidence was observed following treatment with $21 \mu \mathrm{g} / \mathrm{kg}$ b.w, suggesting a non-linear dose-response for renal tumour formation by OTA (NTP, 1989). Kidney tumours in OTA exposed rats develop with a relative rapid onset and are characterized by their malignant and aggressive behaviour (Boorman et al., 1992). In the NTP study, decreased survival rates in the mid- and high dose groups were associated with high incidences of metastasis. Histopathological changes induced by OTA in the kidney consist of disorganization of the S3 tubules, single cell death, karyomegaly, polyploidy and frequent mitosis (Boorman et al., 1992; Maaroufi et al., 1999; Rasonyi et al., 1999). These histopathological alterations together with the aggressive nature of the tumours are unique to OTA and suggest that the mechanism of OTA carcinogenicity is not merely based on sustained regenerative cell proliferation as a consequence of cytotoxicity, as frequently observed in response to non-genotoxic renal carcinogens such as chloroform and d-limonene (Lock and Hard, 2004). However, results of genotoxicity studies also do not suggest that OTA is mutagenic or a potent genotoxin. With respect to the potential of OTA to covalently bind to DNA, conflicting results have been obtained and the purpose of this manuscript is to present a review of the available literature.

\footnotetext{
${ }^{*}$ To whom correspondence should be addressed; e-mail: dekant@ toxi.uni-wuerzburg.de
} 


\section{Genotoxicity}

Results from a range of studies assessing the mutagenicity and genotoxicity of OTA are summarized in Table 1. In most studies, OTA was found to be negative in the Ames-test even in the presence of metabolic activation systems. Increased mutation frequencies were only observed using modifications of the standard Ames-test with culture media from OTA-treated hepatocytes and in the presence of mouse, but not rat kidney microsomes (Hennig et al., 1991; Obrecht-Pflumio et al., 1999). Moreover, OTA was only found to be mutagenic in Salmonella typhimurium strain TA 100 , but not in TA 1535 , although mechanisms of mutagenicity are identical in both strains (Obrecht-Pflumio et al., 1999). In the light of the large number of negative studies, these results are difficult to interpret since they provide no direct evidence for the mutagenicity of OTA and are not consistent with the known species differences in susceptibility to the carcinogenicity of OTA.

However, genotoxic effects such as DNA strand breaks, sister chromatid exchanges, chromosomal aberrations and induction of micronuclei have been observed in some mammalian cell systems in response to OTA exposure. However, in most cases, these effects occurred independently of metabolic activation (Table 1).

\section{Biotransformation}

Biotransformation of OTA to reactive intermediates with the potential to bind to DNA has been suggested to be involved in renal tumour formation by OTA. However, no metabolites indicative of reactive intermediate formation have been detected in rodent blood or urine after OTA-exposure. Results from several studies both in vivo and in vitro indicate that OTA is poorly metabolized both by cytochromes $\mathrm{P} 450$ and by peroxidases (Gautier et al., 2001; Zepnik et al., 2001; Gross-Steinmeyer et al., 2002; Zepnik et al., 2003). The major metabolite formed in vivo is ochratoxin $\alpha$, which results from cleavage of the peptide bond (Zepnik et 
$a l ., 2003)$. In vitro, oxidative biotransformation by cytochromes $\mathrm{P} 450$ yields low amounts of hydroxylated derivatives, but their presence in urine could not be confirmed in recent studies despite the use of sensitive LC-MS/MS analysis (Gautier et al., 2001; Zepnik et al., 2001; Zepnik et al., 2003). However, two novel metabolites formed in rat hepatocytes in vitro and excreted in urine of OTA treated animals were recently identified as hexose- and pentoseconjugates (Gross-Steinmeyer et al., 2002; Zepnik et al., 2003). The OTA metabolites identified are considered to be less toxic than OTA and it is unlikely that their mechanisms of formation involves electrophilic intermediates (Figure 1) (Xiao et al., 1996; Gautier et al., 2001; Zepnik et al., 2001; Gross-Steinmeyer et al., 2002).

By electrochemical and photochemical oxidation of OTA, formation of a hydroquinone/quinone redox couple has recently been reported and speculated to be involved in OTA carcinogenicity (Calcutt et al., 2001). In addition to generation of reactive oxygen species due to redox cycling, the electrophilic quinone may potentially react with tissue nucleophiles to form covalently bound adducts or glutathione conjugates. However, experimental proof of this pathway has not been obtained. Several studies in vitro indicate that OTA does not form DNA adducts even in the presence of activation systems such as horseradish peroxidase which may catalyze formation of the hydroquinone derivative (Gautier et al., 2001; Mally et al., 2004). Moreover, OTA-derived $S$-conjugates which may be directed to the kidney could not be detected (Zepnik et al., 2003; Mally et al., 2004; Mally et al., 2005b). The involvement of a nephrotoxic $S$-conjugate in OTA toxicity and carcinogenicity is also not consistent with the potency of other hydroquinones activated by a glutathioneconjugation pathway, which usually require administration of much higher doses to induce nephrotoxicity (English et al., 1994; Monks and Lau, 1994; Boatman et al., 1996) and/or renal tumours. Furthermore, it is well established that nephrotoxic hydroquinone $S$-conjugates promote tumour formation by inducing sustained regenerative cell proliferation in response to cytotoxicity and tissue necrosis, which is also not consistent with the histopathological 
changes observed after treatment with OTA (NTP, 1989; Boorman et al., 1992; English et al., 1994; Nakagawa et al., 1998; Lock and Hard, 2004).

\section{DNA binding using radiolabelled compound}

The use of radiolabelled compounds combined with liquid scintillation counting or accelerator mass spectrometry (AMS) allows the unambiguous determination as to whether or not the compound of interest covalently binds to DNA. Both decay counting and AMS can produce false positive results if insufficiently pure DNA is used (i.e. contamination with proteins or RNA which often bind reactive intermediates with higher yields) or if parts of the molecule containing radiolabel are metabolically incorporated into DNA. In contrast, negative results by both methods clearly indicate lack of DNA binding.

In three independent studies, binding of OTA to rat kidney DNA could not be demonstrated after administration of ${ }^{3} \mathrm{H}$ or ${ }^{14} \mathrm{C}$-labelled OTA to rodents using liquid scintillation counting $\left({ }^{3} \mathrm{H}\right)$ or AMS $\left({ }^{14} \mathrm{C}\right)$ as analytical procedures (Schlatter et al., 1996; Gautier et al., 2001; Mally et al., 2004). Similarly, adduct formation was not observed by scintillation counting in DNA extracted from rat and human hepatocytes treated with ${ }^{3}$ H-OTA in vitro (Gross-Steinmeyer $e t$ al., 2002). Conditions and results of these studies are summarized in Table 2. Limits of detection in all studies were well below those required to detect "adducts" present in concentrations indicated by ${ }^{32} \mathrm{P}$-postlabelling and doses of OTA administered were similar to those used in the ${ }^{32} \mathrm{P}$-postlabelling experiments. Thus, studies using radiolabelled OTA have been sufficiently sensitive to detect DNA-modifications as indicated by postlabelling containing the OTA-molecule if present.

\section{DNA adduct formation analyzed by ${ }^{32} \mathrm{P}$-postlabelling}

The ${ }^{32} \mathrm{P}$-postlabelling assay is a highly sensitive method for the detection of DNA modifications in response to carcinogen treatment. The postlabelling procedure involves 
isolation and enzymic hydrolysis of DNA from tissues, enrichment of the adduct fraction, enzymic labelling of the $3^{\prime}$-monophosphates using $\left[\gamma^{32} \mathrm{P}\right]$-ATP followed by separation using two-dimensional thin layer chromatography. Adducts "spots" are then detected and quantified by autoradiography. The advantages of ${ }^{32} \mathrm{P}$-postlabelling over other methods such as scintillation counting or AMS are the requirement of only small sample sizes (1-10 $\mu \mathrm{g}$ of DNA), the ability to assess DNA adduct formation when radioactive compound is not available, and the potential to detect DNA base modifications that do not contain parts of the compound of interest, such as oxidative lesions or I-compounds (Randerath et al., 1993). However, thin layer chromatography does not offer high resolution and is often difficult to reproduce. Moreover, labelling of hydroxylated compounds still present in the incubation mixtures and the presence of endogenous DNA base modifications may lead to false positive results, particularly in the absence of reference compounds (Masento et al., 1989; Scates et al., 1995). Incomplete DNA digestion, which can occur in the presence of bulky DNA adducts, may also produce false negative results. Most importantly, postlabelling does not provide structural information and it is not possible to determine if the "adduct" spots observed actually contain covalently bound compound. In this respect, low "adduct" levels of classic non-genotoxic carcinogens, which may alter concentrations of endogenous DNA base modifications but which do not bind to DNA, have been reported and raised concerns that the postlabelling procedure may be too sensitive (Liehr et al., 1993; Randerath et al., 1993).

Using this method, DNA adducts ascribed to OTA have been reported by one laboratory in a wide range of tissues from rodents (summarized in Table 3), pigs after OTA-exposures and from humans presumably exposed to OTA, as well as in various cell lines in response to OTA treatment (Pfohl-Leszkowicz et al., 1993; Grosse et al., 1995; El Adlouni et al., 2000; Arlt et al., 2001; Faucet et al., 2004). In some tissue samples, up to 24 adducts spots were detected. These unusually large numbers of adducts were often reported to be tissue, sex- or species specific and occurred with variable kinetics (some "adducts" disappeared rapidly, others 
persisted). However, "adduct" maps were not consistent over a range of studies and a clear dose-response for the formation of these adducts could not be established. Large numbers of OTA-derived "adducts" have also been reported to be present in mice, which are far less susceptible to OTA carcinogenicity, or in liver DNA of rodents treated with OTA. However, the liver is not a target organ for tumorigenicity or toxicity of OTA (Boorman et al., 1992), further questioning the relevance of the observed "adducts" for OTA carcinogenicity. Frequently, background adduct levels in DNA extracted from control animals were not assessed or were reported to be below the limit of detection. This is in contrast to a large number of studies assessing "endogenous" DNA base modifications (modifications present in control animals) which demonstrate the presence of a number of "spots" in DNA from control animals (Vulimiri et al., 1998; Gupta et al., 1999; Gupta and Lutz, 1999; Zhou et al., 1999). Most importantly, however, "adduct spots" attributed to OTA treatment were never shown to contain parts of the OTA molecule, suggesting that these DNA modifications - if present may be due to oxidative stress or modulation of endogenous DNA base modifications.

Recently, the structures of a photochemically generated carbon- and oxygen-bonded C8OTA-dGMP adduct have been reported. It has been suggested that these compounds represent the DNA-adducts presumably formed from OTA in vivo (Figure 2) (Dai et al., 2003; Faucet et al., 2004). In a recent paper., synthetic standards of these compounds were reported to comigrate with two of the adduct "spots" found in kidney from OTA treated rats(Faucet et al., 2004). This observation has been claimed as evidence for covalent DNA binding of OTA. However, two other laboratories were independently unable to confirm the presence of OTA related "spots" suggestive of DNA-modifications using ${ }^{32}$ P-postlabelling (Mally et al., 2004; Mally et al., 2005a). In these studies, rats were repeatedly given by gavage high doses (up to 2 $\mathrm{mg} / \mathrm{kg}$ b.w.) of OTA (5 days/week for two weeks), which correspond to approximately ten times the top dose used in the NTP bioassay resulting in a renal tumour incidence of $74 \%$. 
This dosing regimen resulted in high plasma and tissue concentrations and OTA-specific histopathological changes in the kidney of treated animals (Mally et al., 2005b). OTA-dGMP adduct standards obtained by photoirradiation of OTA in the presence of dGMP as well as positive controls (aristolochic acid) were included. In these studies, "spots" were detected in OTA-treated animals, but the same "spot" patterns were also present in controls and total "adduct" levels were not increased in response to OTA exposure. Furthermore, formation of the postulated carbon-bonded C8-OTA-dG adduct in response to OTA treatment could not be confirmed using either ${ }^{32} \mathrm{P}$-postlabelling or LC-MS/MS (Mally et al., 2004; Mally et al., 2005a). However, DNA strand breakage was evident in target and non-target tissues as assessed by the Comet Assay. These effects were further enhanced in the presence of formamidopyrimidine glycosylase, which is known to convert oxidative lesions into DNA strand breaks, suggesting that the observed DNA damage may be a result of oxidative stress rather than formation of covalent DNA-adducts (Mally et al., 2005a).

In the context of substantial evidence arguing against metabolic activation and covalent binding to DNA, the results of the study by Faucet et al. (2004) should be interpreted carefully. In this study, only one chromatographic system was applied, which is not very selective and does not offer a high resolution for lipophilic compounds. As previously reported, up to 19 adduct spots were detected in kidney DNA of rats administered OTA for two years $(0.4 \mathrm{mg} / \mathrm{kg}$ b.w., 3 times per week) and all of these migrated to the upper right-hand corner of the plates (Pfohl-Leszkowicz et al., 1998). It is therefore not surprising that the synthetic standard which also migrates to this region co-eluted with one of these spots. Clearly, confirmation of the presence of the postulated OTA-DNA adducts requires further qualifiers such as mass- or UV-spectra or at least co-chromatography in at least two chromatographic systems with high resolution and different selectivities. A clear and reproducible separation is also required. Therefore, it is highly questionable if co- 


\section{Acknowledgements}

Parts of the authors work were supported by the Fifth RTD Framework Programme of the European Union, Project No.: QLK1-2001-01614, by the Institute for Scientific Information on Coffee (ISIC) in Vevey, Switzerland and the Physiological Effects of Coffee Committee (PEC) in Paris, France and by the Deutsche Forschungsgemeinschaft, Bonn. 


\section{References}

Arlt, VM, Pfohl-Leszkowicz, A, Cosyns, J, and Schmeiser, HH. 2001. Analyses of DNA adducts formed by ochratoxin $\mathrm{A}$ and aristolochic acid in patients with Chinese herbs nephropathy. Mutation Research 494: 143-150.

Bendele, AM, Neal, SB, Oberly, TJ, Thompson, CZ, Bewsey, BJ, Hill, LE, Rexroat, MA, Carlton, WW, and Probst, GS. 1985. Evaluation of ochratoxin A for mutagenicity in a battery of bacterial and mammalian cell assays. Food and Chemical Toxicology 23: 911-918.

Boatman, RJ, English, JC, Perry, LG, and Bialecki, VE. 1996. Differences in the nephrotoxicity of hydroquinone among Fischer 344 and Sprague-Dawley rats and B6C3F1 mice. Journal of Toxicology and Environmental Health 47: 159-172.

Boorman, GA, McDonald, MR, Imoto, S, and Persing, R. 1992. Renal lesions induced by ochratoxin A exposure in the F344 rat. Toxicologic Pathology 20: 236-245.

Calcutt, MW, Gillman, IG, Noftle, RE, and Manderville, RA. 2001. Electrochemical oxidation of ochratoxin A: correlation with 4-chlorophenol. Chemical Research in Toxicology 14: 1266-1272.

Castegnaro, M, Mohr, U, Pfohl-Leszkowicz, A, Esteve, J, Steinmann, J, Tillmann, T, Michelon, J, and Bartsch, H. 1998. Sex- and strain-specific induction of renal tumors by ochratoxin A in rats correlates with DNA adduction. International Journal of Cancer 77: 70-75.

Cooray, R. 1984. Effects of some mycotoxins on mitogen-induced blastogenesis and SCE frequency in human lymphocytes. Food and Chemical Toxicology 22: 529-534.

Creppy, EE, Kane, A, Dirheimer, G, Lafarge-Frayssinet, C, Mousset, S, and Frayssinet, C. 1985. Genotoxicity of ochratoxin A in mice: DNA single-strand break evaluation in spleen, liver and kidney. Toxicology Letters 28: 29-35.

Dai, J, Wright, MW, and Manderville, RA. 2003. Ochratoxin a forms a carbon-bonded c8deoxyguanosine nucleoside adduct: implications for c 8 reactivity by a phenolic radical. Journal of the American Chemical Society 125: 3716-3717.

de Groene, EM, Hassing, IG, Blom, MJ, Seinen, W, Fink-Gremmels, J, and Horbach, GJ. 1996. Development of human cytochrome P450-expressing cell lines: application in mutagenicity testing of ochratoxin A. Cancer Research 56: 299-304. 
Dopp, E, Muller, J, Hahnel, C, and Schiffmann, D. 1999. Induction of genotoxic effects and modulation of the intracellular calcium level in syrian hamster embryo (SHE) fibroblasts caused by ochratoxin A. Food and Chemical Toxicology 37: 713-721.

Dorrenhaus, A, and Follmann, W. 1997. Effects of ochratoxin A on DNA repair in cultures of rat hepatocytes and porcine urinary bladder epithelial cells. Archives of Toxicology 71: 709-713.

Ehrlich, V, Darroudi, F, Uhl, M, Steinkellner, H, Gann, M, Majer, BJ, Eisenbauer, M, and Knasmuller, S. 2002. Genotoxic effects of ochratoxin A in human-derived hepatoma (HepG2) cells. Food and Chemical Toxicology 40: 1085-1090.

El Adlouni, C, Pinelli, E, Azemar, B, Zaoui, D, Beaune, P, and Pfohl-Leszkowicz, A. 2000. Phenobarbital increases DNA adduct and metabolites formed by ochratoxin A: role of CYP 2C9 and microsomal glutathione-S-transferase. Environmental and Molecular Mutagenesis 35: 123-131.

English, JC, Perry, LG, Vlaovic, M, Moyer, C, and O'Donoghue, JL. 1994. Measurement of cell proliferation in the kidneys of Fischer 344 and Sprague-Dawley rats after gavage administration of hydroquinone. Fundamental and Applied Toxicology 23: 397-406.

Faucet, V, Pfohl-Leszkowicz, A, Dai, J, Castegnaro, M, and Manderville, RA. 2004. Evidence for covalent DNA adduction by ochratoxin A following chronic exposure to rat and subacute exposure to pig. Chemical Research in Toxicology 17: 1289-1296.

Follmann, W, Hillebrand, IE, Creppy, EE, and Bolt, HM. 1995. Sister chromatid exchange frequency in cultured isolated porcine urinary bladder epithelial cells (PUBEC) treated with ochratoxin A and alpha. Archives of Toxicology 69: 280-286.

Follmann, W, and Lucas, S. 2003. Effects of the mycotoxin ochratoxin A in a bacterial and a mammalian in vitro mutagenicity test system. Archives of Toxicology 77: 298-304.

Gautier, J, Richoz, J, Welti, DH, Markovic, J, Gremaud, E, Guengerich, FP, and Turesky, RJ. 2001. Metabolism of ochratoxin A: absence of formation of genotoxic derivatives by human and rat enzymes. Chemical Research in Toxicology 14: 34-45.

Grosse, Y, Baudrimont, I, Castegnaro, M, Betbeder, AM, Creppy, EE, Dirheimer, G, and Pfohl-Leszkowicz, A. 1995. Formation of ochratoxin A metabolites and DNA-adducts in monkey kidney cells. Chemico-Biological Interactions 95: 175-187.

Gross-Steinmeyer, K, Weymann, J, Hege, HG, and Metzler, M. 2002. Metabolism and lack of DNA reactivity of the mycotoxin ochratoxin a in cultured rat and human primary hepatocytes. Jounral of Agricultural and Food Chemistry 50: 938-945. 
Gupta, RC, Arif, JM, and Gairola, CG. 1999. Enhancement of pre-existing DNA adducts in rodents exposed to cigarette smoke. Mutation Research 424: 195-205.

Gupta, RC, and Lutz, WK. 1999. Background DNA damage for endogenous and unavoidable exogenous carcinogens: a basis for spontaneous cancer incidence? Mutation Research 424: 1-8.

Hennig, A, Fink-Gremmels, J, and Leistner, L. 1991. Mutagenicity and effects of ochratoxin A on the frequency of sister chromatid exchange after metabolic activation. IARC Scientific Publications: 255-260.

Krivobok, S, Olivier, P, Marzin, DR, Seigle-Murandi, F, and Steiman, R. 1987. Study of the genotoxic potential of 17 mycotoxins with the SOS Chromotest. Mutagenesis 2: 433439.

Lebrun, S, and Follmann, W. 2002. Detection of ochratoxin A-induced DNA damage in MDCK cells by alkaline single cell gel electrophoresis (comet assay). Archives of Toxicology 75: 734-741.

Liehr, JG, Han, X, and Bhat, HK. 1993. 32P-postlabelling in studies of hormonal carcinogenesis. IARC Scientific Publications: 149-155.

Lock, EA, and Hard, GC. 2004. Chemically induced renal tubule tumors in the laboratory rat and mouse: review of the NCI/NTP database and categorization of renal carcinogens based on mechanistic information. Critical Reviews in Toxicology 34: 211-299.

Maaroufi, K, Zakhama, A, Baudrimont, I, Achour, A, Abid, S, Ellouz, F, Dhouib, S, Creppy, EE, and Bacha, H. 1999. Karyomegaly of tubular cells as early stage marker of the nephrotoxicity induced by ochratoxin A in rats. Human and Experimental Toxicology 18: 410-415.

Malaveille, C, Brun, G, and Bartsch, H. 1991. Genotoxicity of ochratoxin A and structurally related compounds in Escherichia coli strains: studies on their mode of action. IARC Scientific Publications: 261-266.

Mally, A, Pepe, G, Ravoori, S, Fiore, M, Gupta, R, Dekant, W, and Mosesso, P. 2005a. Ochratoxin A causes DNA-damage and cytogenetic effects, but no DNA-adducts in rats. Chemical Research in Toxicology in press.

Mally, A, Völkel, W, Amberg, A, Kurz, M, Wanek, P, Eder, E, Hard, G, and Dekant, W. 2005b. Functional, biochemical and pathological effects of repeated administration of ochratoxin A to rats. Chemical Research in Toxicology. in press. 
Mally, A, Zepnik, H, Wanek, P, Eder, E, Dingley, K, Ihmels, H, Völkel, W, and Dekant, W. 2004. Ochratoxin A: Lack of formation of covalent DNA adducts. Chemical Research in Toxicology 17: 234-242.

Masento, MS, Hewer, A, Grover, PL, and Phillips, DH. 1989. Enzyme-mediated phosphorylation of polycyclic hydrocarbon metabolites: detection of non-adduct compounds in the 32P-postlabelling assay. Carcinogenesis 10: 1557-1559.

Miljkovic, A, Pfohl-Leszkowicz, A, Dobrota, M, and Mantle, PG. 2003. Comparative responses to mode of oral administration and dose of ochratoxin A or nephrotoxic extract of Penicillium polonicum in rats. Experimental and Toxicological Pathology 54: 305-312.

Monks, T, and Lau, S. 1994. Glutathione Conjugation as a Mechanism for the Transport of Reactive Metabolites. In Conjugation-Dependent Carcinogenicity and Toxicity of Foreign Compounds (M Anders, and W Dekant, Eds.). Academic Press, Inc., San Diego.

Mori, H, Kawai, K, Ohbayashi, F, Kuniyasu, T, Yamazaki, M, Hamasaki, T, and Williams, GM. 1984. Genotoxicity of a variety of mycotoxins in the hepatocyte primary culture/DNA repair test using rat and mouse hepatocytes. Cancer Research 44: 29182923.

Nakagawa, Y, Kitahori, Y, Cho, M, Konishi, N, Tsumatani, K, Ozono, S, Okajima, E, Hirao, Y, and Hiasa, Y. 1998. Effect of hexachloro-1,3-butadiene on renal carcinogenesis in male rats pretreated with N-ethyl-N-hydroxyethylnitrosamine. Toxicologic Pathology 26: 361-366.

NTP. 1989. Toxicology and Carcinogenesis Studies of Ochratoxin A (CAS No. 303-47-9) in F344/N Rats (Gavage Studies). Nationall Toxicology Program Technical Report Series 358: 1-142.

Obrecht-Pflumio, S, Chassat, T, Dirheimer, G, and Marzin, D. 1999. Genotoxicity of ochratoxin A by Salmonella mutagenicity test after bioactivation by mouse kidney microsomes. Mutation Research 446: 95-102.

Obrecht-Pflumio, S, Grosse, Y, Pfohl-Leszkowicz, A, and Dirheimer, G. 1996. Protection by indomethacin and aspirin against genotoxicity of ochratoxin A, particularly in the urinary bladder and kidney. Archives of Toxicology 70: 244-248.

Petkova-Bocharova, T, Stoichev, II, Chernozemsky, IN, Castegnaro, M, and PfohlLeszkowicz, A. 1998. Formation of DNA adducts in tissues of mouse progeny through transplacental contamination and/or lactation after administration of a single dose of 
ochratoxin A to the pregnant mother. Environmental and Molecular Mutagenesis 32: 155-162.

Pfohl-Leskowicz, A, Bartsch, H, Azemar, B, Mohr, U, Esteve, J, and Castegnaro, M. 2002. Mesna protects rats against nephrotoxicity but not carcinogenicity induced by ochratoxin A, implicating two separate pathways. Facta Universitatis, Medicine and Biology 9: 57-63.

Pfohl-Leszkowicz, A, Chakor, K, Creppy, EE, and Dirheimer, G. 1991. DNA adduct formation in mice treated with ochratoxin A. IARC Scientific Publications: 245-253.

Pfohl-Leszkowicz, A, Grosse, Y, Castegnaro, M, Nicolov, IG, Chernozemsky, IN, Bartsch, H, Betbeder, AM, Creppy, EE, and Dirheimer, G. 1993. Ochratoxin A-related DNA adducts in urinary tract tumours of Bulgarian subjects. IARC Scientific Publications: 141-148.

Pfohl-Leszkowicz, A, Pinelli, E, Bartsch, H, Mohr, U, and Castegnaro, M. 1998. Sex- and strain-specific expression of cytochrome P450s in ochratoxin A-induced genotoxicity and carcinogenicity in rats. Molecular Carcinogenesis 23: 76-85.

Randerath, K, Li, D, Moorthy, B, and Randerath, E. 1993. I-compounds--endogenous DNA markers of nutritional status, ageing, tumour promotion and carcinogenesis. IARC Scientific Publications: 157-165.

Rasonyi, T, Schlatter, J, and Dietrich, DR. 1999. The role of alpha2u-globulin in ochratoxin A induced renal toxicity and tumors in F344 rats. Toxicology Letters 104: 83-92.

Sakai, M, Abe, K, Okumura, H, Kawamura, O, Sugiura, Y, Horie, Y, and Ueno, Y. 1992. Genotoxicity of fungi evaluated by SOS microplate assay. Natural Toxins 1: 27-34.

Scates, DK, Spigelman, AD, and Venitt, S. 1995. Appearance of artefacts when using ${ }^{32} \mathrm{P}-$ postlabelling to investigate DNA adduct formation by bile acids in vitro: lack of evidence for covalent binding. Carcinogenesis 16: 1489-1491.

Schlatter, C, Studer-Rohr, J, and Rasonyi, T. 1996. Carcinogenicity and kinetic aspects of ochratoxin A. Food Additives and Contaminants 13 Suppl: 43-44.

Stetina, R, and Votava, M. 1986. Induction of DNA single-strand breaks and DNA synthesis inhibition by patulin, ochratoxin A, citrinin, and aflatoxin $\mathrm{B} 1$ in cell lines $\mathrm{CHO}$ and AWRF. Folia Biologica (Praha) 32: 128-144.

Umeda, M, Tsutsui, T, and Saito, M. 1977. Mutagenicity and inducibility of DNA singlestrand breaks and chromosome aberrations by various mycotoxins. Gann 68: 619-625. 
Vulimiri, SV, Zhou, GD, Randerath, K, and Randerath, E. 1998. High levels of endogenous DNA adducts (I-compounds) in pig liver. Modulation by high cholesterol/high fat diet. Mutation Research 422: 297-311.

Wehner, FC, Thiel, PG, van Rensburg, SJ, and Demasius, IP. 1978. Mutagenicity to Salmonella typhimurium of some Aspergillus and Penicillium mycotoxins. Mutation Research 58: 193-203.

Wurgler, FE, Friederich, U, and Schlatter, J. 1991. Lack of mutagenicity of ochratoxin A and $\mathrm{B}$, citrinin, patulin and cnestine in Salmonella typhimurium TA102. Mutation Research 261: 209-216.

Xiao, H, Madhyastha, S, Marquardt, RR, Li, S, Vodela, JK, Frohlich, AA, and Kemppainen, BW. 1996. Toxicity of ochratoxin A, its opened lactone form and several of its analogs: structure-activity relationships. Toxicology and Applied Pharmacology 137: 182-192.

Zepnik, H, Pahler, A, Schauer, U, and Dekant, W. 2001. Ochratoxin A-induced tumor formation: is there a role of reactive ochratoxin A metabolites? Toxicological Sciences 59: 59-67.

Zepnik, H, Volkel, W, and Dekant, W. 2003. Toxicokinetics of the mycotoxin ochratoxin A in F 344 rats after oral administration. Toxicology and Applied Pharmacology 192: $36-44$.

Zhou, GD, Hernandez, NS, Randerath, E, and Randerath, K. 1999. Acute elevation by shortterm dietary restriction or food deprivation of type I I-compound levels in rat liver DNA. Nutrition and Cancer 35: 87-95. 
Table $1 \quad$ Mutagenicity and genotoxicity of ochratoxin A in vitro

\begin{tabular}{|c|c|c|}
\hline Test system & $\begin{array}{c}\text { Results } \\
\text { (positive / negative) }\end{array}$ & Reference \\
\hline $\begin{array}{l}\text { Ames Test } \\
\text { S. typhimurium TA 98, 100, 1535, } \\
1537,1538\end{array}$ & negative & (Wehner et al., 1978) \\
\hline S. typhimurium TA 102 & negative & (Wurgler et al., 1991) \\
\hline $\begin{array}{l}\text { S. typhimurium TA 98, 100, 1535, } \\
1537,1538\end{array}$ & negative & (Bendele et al., 1985) \\
\hline $\begin{array}{l}\text { S. typhimurium TA 98, 100, 1535, } \\
1538,102,104\end{array}$ & negative & $\begin{array}{l}\text { (Follmann and Lucas, } \\
\text { 2003) }\end{array}$ \\
\hline S. typhimurium TA $97,98,100,1535$ & negative & $(\mathrm{NTP}, 1989)$ \\
\hline S. typhimurium TA 100, 2638 & negative & (Zepnik et al., 2001) \\
\hline S. typhimurium TA 98, 1535, 1538 & $\begin{array}{c}\text { positive } \\
\text { (in the presence of mouse, } \\
\text { but not rat kidney } \\
\text { microsomes) }\end{array}$ & $\begin{array}{l}\text { (Obrecht-Pflumio et al., } \\
\text { 1999) }\end{array}$ \\
\hline S. typhimurium TA 100, 1535, 1538 & $\begin{array}{c}\text { positive } \\
\text { (hepatocyte culture medium) }\end{array}$ & (Hennig et al., 1991) \\
\hline SOS DNA Reparatur & negative & (Sakai et al., 1992) \\
\hline $\begin{array}{l}\text { Sos Chromotest } \\
\text { E. coli PQ 35, } 37\end{array}$ & negative & (Krivobok et al., 1987) \\
\hline E. coli PQ 35, 37 & $\begin{array}{c}\text { positive } \\
\text { (at cytotoxic concentrations) }\end{array}$ & (Malaveille et al., 1991) \\
\hline $\begin{array}{l}\text { Mutagenicity in mammalian cells } \\
\text { L5178Y TK+/- mouse lymphoma cells }\end{array}$ & negative & (Bendele et al., 1985) \\
\hline HPRT & negative & (Umeda et al., 1977) \\
\hline $\begin{array}{l}\text { lacZ゙-mutations (NIH/3T3 mouse } \\
\text { fibroblasts expressing human CYP450 }\end{array}$ & positive & (de Groene et al., 1996) \\
\hline $\begin{array}{l}\text { DNA repair } \\
\text { rat and mouse hepatocytes }\end{array}$ & $\begin{array}{c}\text { positive } \\
\text { (weak effects only at } \\
\text { cytotoxic concentrations) }\end{array}$ & (Mori et al., 1984) \\
\hline rat hepatocytes & negative & (Bendele et al., 1985) \\
\hline rat hepatocytes & positive & $\begin{array}{l}\text { (Dorrenhaus and } \\
\text { Follmann, 1997) } \\
\end{array}$ \\
\hline $\begin{array}{l}\text { DNA strand breaks } \\
\text { Chinese hamster ovary cells } \\
\text { rat fibroblasts }\end{array}$ & positive & $\begin{array}{l}\text { (Stetina and Votava, } \\
\text { 1986) }\end{array}$ \\
\hline mouse splenocytes & positive & (Creppy et al., 1985) \\
\hline MDCK kidney epithelial cells & positive & $\begin{array}{l}\text { (Lebrun and Follmann, } \\
\text { 2002) }\end{array}$ \\
\hline HepG2 cells & positive & (Ehrlich et al., 2002) \\
\hline $\begin{array}{l}\text { Micronuclei-Test } \\
\text { Syrian embryo fibroblasts }\end{array}$ & positive & (Dopp et al., 1999) \\
\hline HepG2 cells & positive & (Ehrlich et al., 2002) \\
\hline $\begin{array}{l}\text { Sister Chromatid Exchange } \\
\text { Chinese hamster ovary cells }\end{array}$ & negative & $(\mathrm{NTP}, 1989)$ \\
\hline porcine urinary bladder epithelial cells & positive & (Follmann et al., 1995) \\
\hline human lymphocytes & positive (?) & (Hennig et al., 1991) \\
\hline human lymphocytes & negative & (Cooray, 1984) \\
\hline
\end{tabular}


Table 2 Results from DNA binding studies using radiolabelled ochratoxin A

\begin{tabular}{|l|l|l|l|}
\hline Treatment conditions & Results & Limit of detection & Reference \\
\hline $\begin{array}{l}\text { Male rat, single oral dose } \\
\text { of } 1 \mathrm{mg} / \mathrm{kg} \text { b.w., } 24 \mathrm{~h}\end{array}$ & $\begin{array}{l}\text { No adducts detected, } \\
{ }^{3} \mathrm{H}\end{array}$ & $2.7 / 10^{9}$ DNA bases & (Gautier et al., 2001) \\
\hline $\begin{array}{l}\text { Rats, single oral dose of } \\
210 \mu \mathrm{g} / \mathrm{kg}, 24 \mathrm{~h}\end{array}$ & $\begin{array}{l}\text { No adducts detected, } \\
{ }^{3} \mathrm{H}\end{array}$ & $1.3 / 10^{10}$ DNA bases & (Schlatter et al., 1996) \\
\hline $\begin{array}{l}\text { Rats, single oral dose of } \\
500 \mu \mathrm{g} / \mathrm{kg}, 48 \mathrm{~h}\end{array}$ & $\begin{array}{l}\text { No adducts detected, } \\
{ }^{14} \mathrm{C}\end{array}$ & $<3 / 10^{9}$ DNA bases & (Mally et al., 2004) \\
\hline $\begin{array}{l}\text { Human and rat } \\
\text { hepatocytes }\end{array}$ & $\begin{array}{l}\text { No adducts detected, } \\
{ }^{3} \mathrm{H}\end{array}$ & $2 / 10^{9}$ DNA bases & $\begin{array}{l}\text { (Gross-Steinmeyer } \text { et } \\
\text { al., 2002) }\end{array}$ \\
\hline
\end{tabular}


Table 3 Results from a range of in vivo studies using ${ }^{32} \mathrm{P}$-postlabelling to assess DNA adduct formation by ochratoxin A.

\begin{tabular}{|c|c|c|c|c|}
\hline Species/Strain & Dosing regimen & DNA adducts in kidney & Comments / Conclusions & Reference \\
\hline$\Gamma$ Swiss mice & $\begin{array}{l}2.5 \mathrm{mg} / \mathrm{kg} \text { b.w. by gavage } \\
\text { sacrifice } 24-72 \mathrm{~h} \text { after single dose }\end{array}$ & $\begin{array}{l}24 \text { adduct spots } \\
\text { maximum adduct levels after } 72 \mathrm{~h} \\
40 / 10^{9} \text { nucleotides, } \\
\text { no background }\end{array}$ & $\begin{array}{l}9 \text { adduct spots in liver } \\
\text { maximum adduct levels after } 72 \mathrm{~h} \\
7 / 10^{9} \text { nucleotides }\end{array}$ & $\begin{array}{l}\text { (Pfohl-Leszkowicz et al., } \\
\text { 1991) }\end{array}$ \\
\hline$\Gamma$ Swiss mice & $\begin{array}{l}2.5 \mathrm{mg} / \mathrm{kg} \text { b.w. by gavage } \\
\text { sacrifice } 8-384 \mathrm{~h} \text { after single dose }\end{array}$ & $\begin{array}{l}24 \text { adduct spots } \\
\text { maximum adduct levels after } 48 \mathrm{~h} \\
103 / 10^{9} \text { nucleotides, } \\
\text { no background }\end{array}$ & $\begin{array}{l}15 \text { adduct spots in liver } \\
\text { maximum adduct levels after } 48 \mathrm{~h} \\
42 / 10^{9} \text { nucleotides } \\
\text { no background }\end{array}$ & $\begin{array}{l}\text { (Pfohl-Leszkowicz et al., } \\
\text { 1993) }\end{array}$ \\
\hline$\Gamma$ Swiss mice & $\begin{array}{l}2.0 \mathrm{mg} / \mathrm{kg} \text { b.w. by gavage } \\
\text { sacrifice } 48 \mathrm{~h} \text { after single dose }\end{array}$ & $\begin{array}{l}221 / 10^{9} \text { nucleotides, } \\
\text { no background }\end{array}$ & $\begin{array}{l}\text { pretreatment with indomethacin and aspirin reduced adduct } \\
\text { formation by } 95 \% \text { : involvement of prostaglandin- } \mathrm{H} \text {-synthethase } \\
\text { suggested }\end{array}$ & $\begin{array}{l}\text { (Obrecht-Pflumio et al., } \\
\text { 1996) }\end{array}$ \\
\hline E BDF1-C57B1 mice & $\begin{array}{l}0.5 \mathrm{mg} / \mathrm{kg} \mathrm{b} . \mathrm{w} . \text { by gavage } \\
2 \mathrm{mg} / \mathrm{kg} \mathrm{b.w.} \mathrm{by} \mathrm{gavage} \\
\text { sacrifice } 48 \mathrm{~h} \text { after single dose }\end{array}$ & $\begin{array}{l}5 \text { adduct spots } \\
4.5 / 10^{9} \text { nucleotides } \\
13 / 10^{9} \text { nucleotides } \\
\text { no background }\end{array}$ & $\begin{array}{l}15 \text { adduct spots in liver } \\
66 / 10^{9} \text { nucleotides } \\
984 / 10^{9} \text { nucleotides }\end{array}$ & $\begin{array}{l}\text { (Petkova-Bocharova et } \\
\text { al., 1998) }\end{array}$ \\
\hline$\Gamma$ Sprague Dawley rats & $\begin{array}{l}0.2 \mathrm{mg}(/ \mathrm{kg} \text { b.w.?) by gavage } \\
1.0 \mathrm{mg}(/ \mathrm{kg} \text { b.w.?) by gavage } \\
0.2 \mathrm{mg}(/ \mathrm{kg} \mathrm{b} \text { b. } .) \text { in feed } \\
1.0 \mathrm{mg}(/ \mathrm{kg} \mathrm{b} \text { b.w.?) in feed } \\
\text { for } 5 \text { days, sacrifice on day } 6\end{array}$ & $\begin{array}{l}22 / 10^{9} \text { nucleotides } \\
41 / 10^{9} \text { nucleotides } \\
6 / 10^{9} \text { nucleotides } \\
11 / 10^{9} \text { nucleotides }\end{array}$ & $\begin{array}{ccc}\text { OTA in plasma } & 5.9 \mu \mathrm{g} / \mathrm{ml} & (14.6 \mu \mathrm{M}) \\
42.4 \mu \mathrm{g} / \mathrm{ml} & (105.3 \mu \mathrm{M}) \\
5.7 \mu \mathrm{g} / \mathrm{ml} & (14.0 \mu \mathrm{M}) \\
31.0 \mu \mathrm{\mu g} / \mathrm{ml} & (77.0 \mu \mathrm{M}) \\
& \\
\text { kidney pathology and loss of body weight only after } 1 \mathrm{mg} \text { by gavage }\end{array}$ & (Miljkovic et al., 2003) \\
\hline$\Gamma$ Lewis rats & $\begin{array}{l}2 \mathrm{mg} / \mathrm{kg} \text { b.w. by gavage } \\
\text { sacrifice } 48 \mathrm{~h} \text { after single dose }\end{array}$ & $\begin{array}{l}12 \text { adduct spots } \\
70 / 10^{9} \text { nucleotides }\end{array}$ & $\begin{array}{l}\text { pretreatment with } \mathrm{N} \text {-acetyl-cysteine, acivcin or buthionine- } \\
\text { sulfoximine reduced addduct formation: involvement of oxidative } \\
\text { stress and a glutathione conjugate suggested }\end{array}$ & $\begin{array}{l}\text { (Pfohl-Leskowicz et al., } \\
\text { 2002) }\end{array}$ \\
\hline$\Gamma$ Lewis rats & $\begin{array}{l}0.4 \mathrm{mg} / \mathrm{kg} \text { b.w. by gavage } \\
3 \text { times / week for } 2 \text { years }\end{array}$ & $\begin{array}{l}\text { up to } 10 \text { adduct spots } \\
4 \text { to } 25 / 10^{9} \text { nucleotides }\end{array}$ & $\begin{array}{l}\text { cotreatment with MESNA reduced adduct formation: } \\
\text { involvement of a glutathione conjugate suggested } \\
\text { Dark Agouty more susceptible than Lewis rats: CYP 2C and CYP } \\
\text { 1A implicated in OTA genotoxicity }\end{array}$ & $\begin{array}{l}\text { (Pfohl-Leskowicz et al., } \\
2002) \\
\text { (Castegnaro et al., 1998) }\end{array}$ \\
\hline$\Gamma$ Dark Agouti rats & $\begin{array}{l}0.4 \mathrm{mg} / \mathrm{kg} \mathrm{b.w.} \mathrm{by} \mathrm{gavage} \\
3 \text { times / week for } 2 \text { years }\end{array}$ & $\begin{array}{l}\text { up to } 12 \text { adduct spots } \\
2.6 \text { to } 114 / 10^{9} \text { nucleotides } \\
\text { background } 0.5 / 10^{9} \text { nucleotides }\end{array}$ & & $\begin{array}{l}\text { (Pfohl-Leskowicz et al., } \\
\text { 2002) } \\
\text { (Castegnaro et al., 1998) }\end{array}$ \\
\hline $\begin{array}{l}\Gamma \text { Dark Agouti or Lewis } \\
\text { rat? }\end{array}$ & $\begin{array}{l}0.4 \mathrm{mg} / \mathrm{kg} \text { b.w. by gavage } \\
3 \text { times / week for } 2 \text { years }\end{array}$ & 2 distinct adduct spots & & (Arlt et al., 2001) \\
\hline$\Gamma$ Dark Agouti rats & $\begin{array}{l}0.4 \mathrm{mg} / \mathrm{kg} \text { b.w. by gavage } \\
3 \text { times / week for } 2 \text { years }\end{array}$ & up to 19 adduct spots & $+\gamma$ & $\begin{array}{l}\text { (Pfohl-Leszkowicz et al., } \\
\text { 1998) }\end{array}$ \\
\hline$\Gamma$ F344 rats & $\begin{array}{l}1 \mathrm{mg} / \mathrm{kg} \mathrm{b} . \mathrm{w} . \text { by gavage } \\
\text { sacrifice } 24 \mathrm{~h} \text { after single dose }\end{array}$ & $\begin{array}{l}31-71 / 10^{9} \text { nucleotides } \\
\text { background } 6-24 / 10^{9} \text { nucleotides }\end{array}$ & $\begin{array}{l}\text { no binding of }{ }^{3} \mathrm{H} \text {-ochratoxin A to DNA detected, suggesting spots } \\
\text { observed by postlabelling may be caused by oxidative stress and/or } \\
\text { cytotoxicity }\end{array}$ & (Gautier et al., 2001) \\
\hline$\Gamma$ F344 rats & $\begin{array}{l}2 \mathrm{mg} / \mathrm{kg} \mathrm{b} . \mathrm{w} . \text { by gavage } \\
5 \text { times / week for } 2 \text { weeks, sacrifice } \\
72 \mathrm{~h} \text { after final dose }\end{array}$ & no treatment related adducts detected & & (Mally et al., 2004) \\
\hline$\Gamma$ F344 rats & $\begin{array}{l}0.5-2 \mathrm{mg} / \mathrm{kg} \text { b.w. by gavage } \\
5 \text { times / week for } 2 \text { weeks, sacrifice } \\
72 \mathrm{~h} \text { after final dose }\end{array}$ & no treatment related adducts detected & $\begin{array}{l}\text { dhigh blood and organ concentrations of OTA at terminal sacrifice, } \\
\text { prominent kidney pathology, (oxidative) DNA damage present as } \\
\text { indicated by the Comet Assay }\end{array}$ & (Mally et al., 2005a) \\
\hline
\end{tabular}




\section{Figure legends}

Fig. 1 Biotransformation of Ochratoxin A

Fig. 2 Chemical structure of a carbon- and an oxygen-bonded C8-deoxyguanosine formed by photorirradiation of OTA in the presence of dGMP. 
Fig. 1

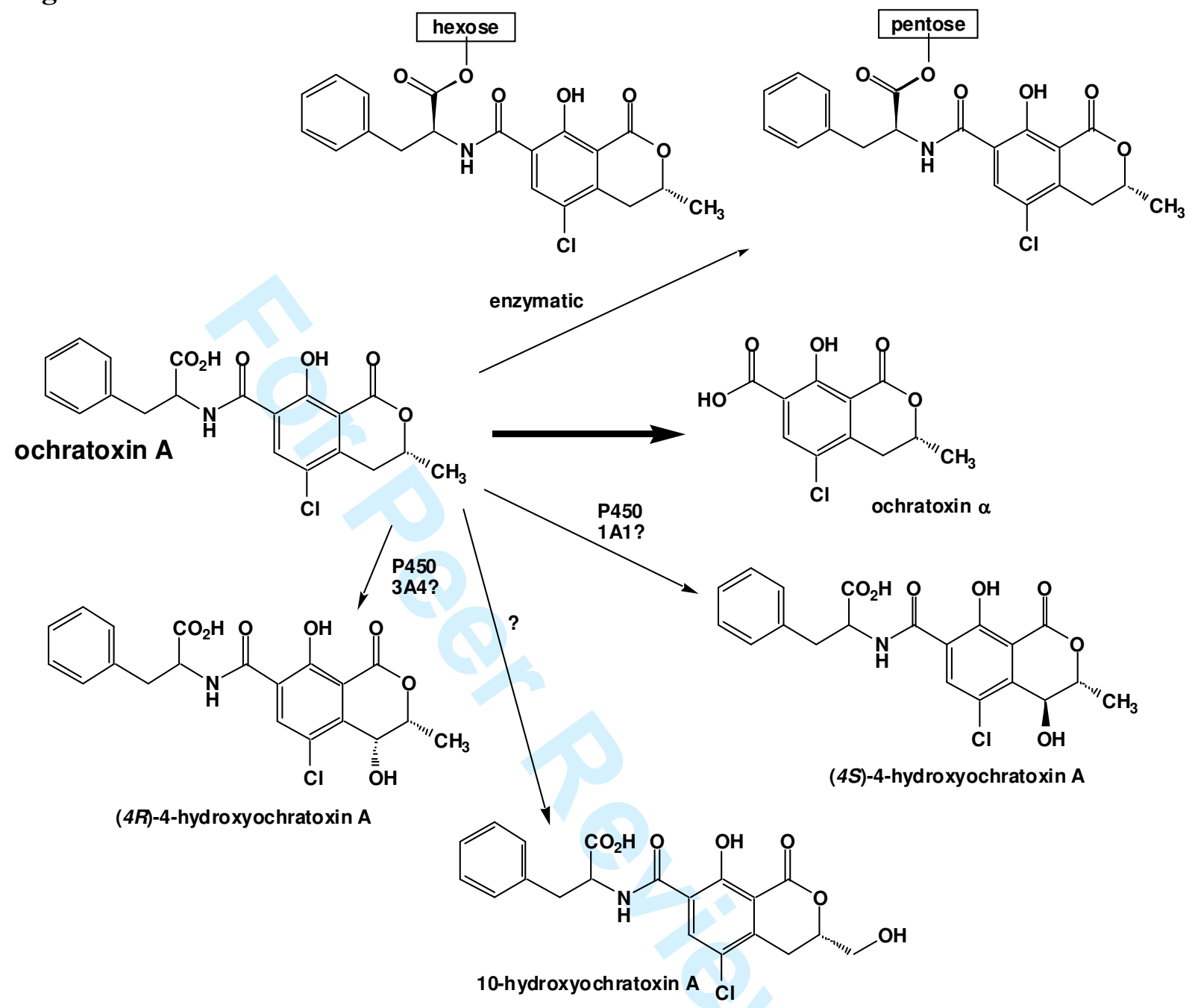


Fig. 2

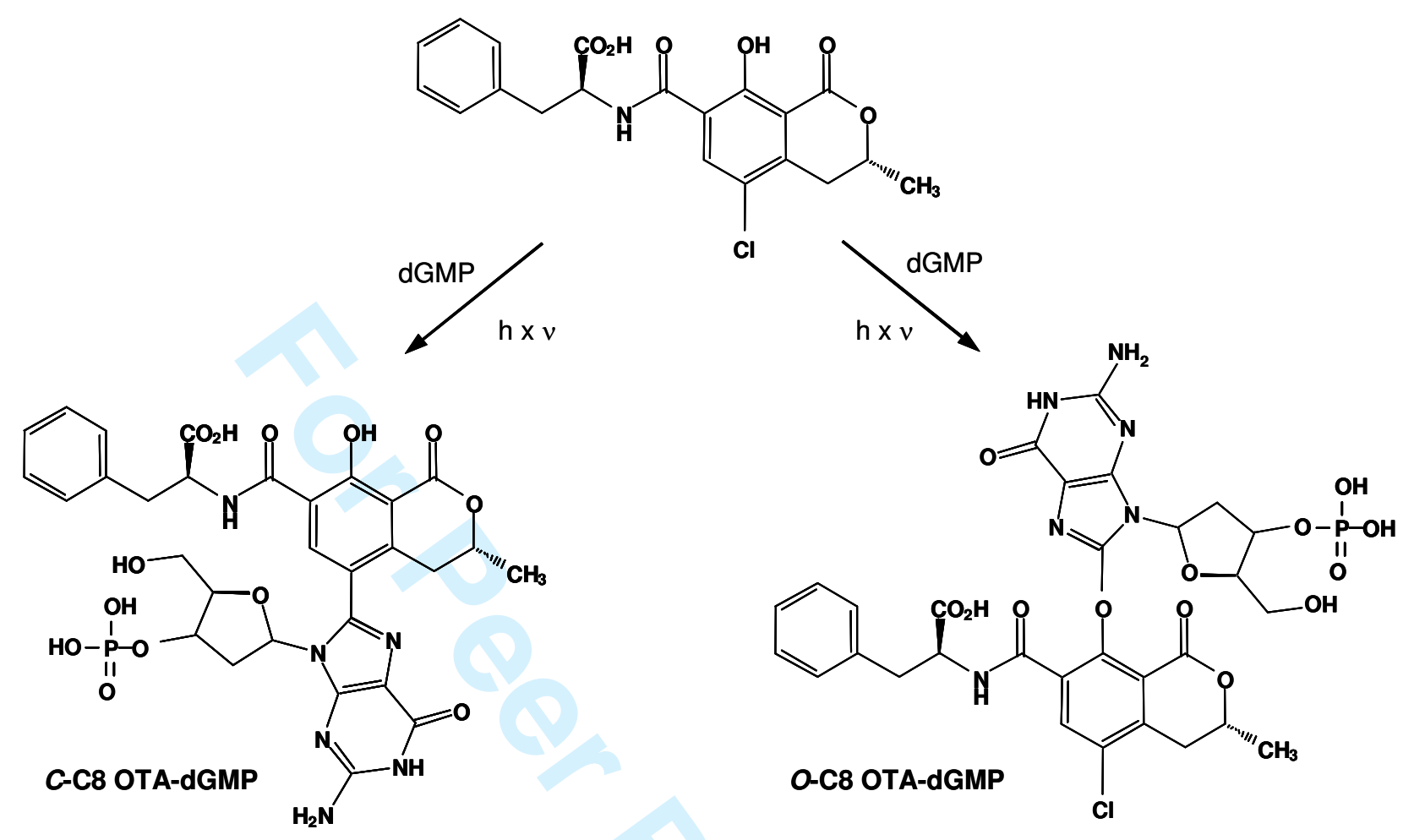

